\title{
CrystEngComm
}

Cite this: CrystEngComm, 2014, 16, 5560

Received 26th December 2013, Accepted 10th April 2014

DOI: $10.1039 / c 3 c e 42633 e$

www.rsc.org/crystengcomm

\section{Mechanochemical synthesis and characterisation of two new bismuth metal organic frameworks $\dagger$}

\author{
L. Tröbs, M. Wilke, W. Szczerba, U. Reinholz and F. Emmerling*
}

\begin{abstract}
Two metal organic structures composed of the ligands benzene-1,4-dicarboxylate and pyridine-2,5-dicarboxylate and bismuth cations are presented: $\left(\mathrm{H}_{2} \mathrm{Im}\right)\left[\mathrm{Bi}(1,4-\mathrm{bdc})_{2}\right](1)$ and $\left[\mathrm{Bi}(\mathrm{pydc})\left(\mathrm{NO}_{3}\right)_{2}\left(\mathrm{H}_{2} \mathrm{O}\right)_{2}\right] \cdot \mathrm{H}_{2} \mathrm{O}(2)(\mathrm{bdc}=$ benzenedicarboxylate, $\mathrm{H}_{2} \mathrm{Im}$ = imidazole cation, pydc = pyridinedicarboxylate). Both compounds were synthesised via grinding and the crystal structure of compound (2) was solved based on its powder diffraction pattern. Compound 1 crystallised isostructurally to the dimethyl ammonium containing compound (dma)[Bi(1,4-bdc) $)_{2}$. Raman spectroscopy and extended X-ray absorption fine structure (EXAFS) measurements provided additional information about the two mechanochemically synthesised metal organic compounds.
\end{abstract}

\section{Introduction}

The synthesis and thorough characterisation of novel metal organic compounds and metal organic frameworks (MOFs) are of considerable scientific interest due to their manifold properties. ${ }^{1-4}$ Possible applications of these compounds range from gas storage and gas separation to drug-carrier, magnetism, and catalysis. ${ }^{4-8}$ Metal organic compounds consist of different tunable molecular structures and have accordingly a large variety of possible architectures and topologies. Typically, transition metals are employed as metal centres in MOFs, whereas examples including main group metals are scarce. ${ }^{9-11}$ In this context, MOFs containing bismuth as the metal centre are currently investigated in greater detail. ${ }^{12}$ Connected via organic ligands, bismuth cations offer a wide range of structural diversity. $\mathrm{Bi}^{3+}$ cations are known for their stereoactive lone pair leading to interesting and versatile coordination geometries. ${ }^{13}$ Moreover, bismuth shows low toxicity even though its position in the periodic table suggests contrary findings. The pharmaceutical value of bismuth and its complexes are well documented, e.g. bismuth subsalicylate complexes have been used successfully for the treatment of gastritis and similar stomach diseases. ${ }^{14,15}$

Dicarboxylate ligands are widely used to link metal centres in metal organic frameworks. In combination with $\mathrm{Bi}^{3+}$ cations as inorganic metal centres, the structural diversity is even higher. Recently, a number of metal organic compounds

BAM Federal Institute for Materials Research and Testing, Richard-Willstätter-Str. 11, 12489 Berlin, Germany. E-mail: franziska.emmerling@bam.de;

Fax: +49 308104 1139; Tel: +49308104 1133

$\dagger$ Electronic supplementary information (ESI) available. CCDC-978120 contains the supplementary crystallographic data for $\left[\mathrm{Bi}(\mathrm{pydc})\left(\mathrm{NO}_{3}\right)_{2}\left(\mathrm{H}_{2} \mathrm{O}\right)_{2}\right] \cdot \mathrm{H}_{2} \mathrm{O}$ (2). For ESI and crystallographic data in CIF or other electronic format see DOI: $10.1039 / \mathrm{c} 3 \mathrm{ce} 42633 \mathrm{e}$ including bismuth centres and dicarboxylate ligands have been reported. ${ }^{12,16-21}$ Small changes in the synthesis of these compounds can lead to different crystalline structures. Thirumurugan et al. reported four different MOF structures including $\mathrm{Bi}^{3+}$ cations and benzene-1,4-dicarboxylate synthesised by changing the metal precursor or the reducing agent. ${ }^{12}$ Recently, Wibowo et al. presented solvothermal and hydrothermal syntheses of three different bismuth-pyridine-2,5-dicarboxylate structures by varying the applied base from potassium hydroxide to sodium hydroxide. ${ }^{16}$ These syntheses require a certain amount of solvents and reaction times up to several days. Here, mechanochemical syntheses are an efficient and fast alternative. ${ }^{22-27}$ Mechanochemistry prevents the use of large amounts of solvents and proceeds at ambient temperatures. Typically, pure products are obtained in high yields within minutes.

In the present work, two metal organic compounds containing $\mathrm{Bi}^{3+}$ cations as metal centres and benzene-1,4-dicarboxylate $\left(\left(\mathrm{H}_{2} \mathrm{Im}\right)\left[\mathrm{Bi}(1,4-\mathrm{bdc})_{2}\right] \quad\right.$ (1)) or pyridine-2,5-dicarboxylate ([Bi(pydc) $\left.\left(\mathrm{NO}_{3}\right)_{2}\left(\mathrm{H}_{2} \mathrm{O}\right)_{2}\right] \cdot \mathrm{H}_{2} \mathrm{O}$ (2)) as ligands are presented. Both compounds were synthesised mechanochemically. Compound (1) is the solvent free analogue to the dma containing MOF reported by Thirumurugan et al. The crystal structure of (2) was solved and refined from powder diffraction data. The characterisation of the crystal structures was carried out by Raman spectroscopy and EXAFS measurements.

\section{Results and discussion}

Two metal carboxylates including $\mathrm{Bi}^{3+}$ cations and benzene-1,4-dicarboxylate $\quad\left(\left(\mathrm{H}_{2} \mathrm{Im}\right)\left[\mathrm{Bi}(1,4-b d c)_{2}\right] \quad(1)\right)$ or pyridine-2,5-dicarboxylate $\left(\left[\mathrm{Bi}(\right.\right.$ pydc $\left.)\left(\mathrm{NO}_{3}\right)_{2}\left(\mathrm{H}_{2} \mathrm{O}\right)_{2}\right] \cdot \mathrm{H}_{2} \mathrm{O} \quad$ (2)) have been synthesised mechanochemically. For both syntheses, bismuth(III) nitrate pentahydrate was used as the 
precursor. Compound (1) was synthesised by grinding bismuth(III) nitrate pentahydrate together with the ligand benzene-1,4-dicarboxylic acid and imidazole as the proton acceptor in the ratio 1:2:4 (Scheme 1). Under mechanochemical conditions, bismuth nitrate decomposes and $\mathrm{HNO}_{3}$ evaporates from the reaction mixture after opening the grinding jar. The completeness of the reaction was confirmed by powder X-ray diffraction measurements (Fig. 1, top). A comparison with database entries revealed a good agreement of the XRD pattern of (1) with the diffraction pattern of $(\mathrm{dma})\left[\mathrm{Bi}(1,4-\mathrm{bdc})_{2}\right](\mathrm{dma}=$ dimethylammonium $)($ Fig. 1, top $){ }^{12}$ It is reasonable that the protonated imidazole cations replace the dma cations in the structure obtained under mechanochemical conditions leading to an isotypic structure.

For the synthesis of compound (2) bismuth(III) nitrate pentahydrate, pyridine-2,5-dicarboxylic acid and a small amount of sodium hydroxide solution $(200 \mu \mathrm{L}, 1 \mathrm{M})$ were ground together for 15 minutes. Sodium hydroxide acts as the reducing agent during the reaction.

The comparison of the powder diffraction patterns of bismuth(III) nitrate pentahydrate, pyridine-2,5-dicarboxylic acid and the product (2) indicates the completeness of the reaction (see Fig. 1, bottom). The diffraction pattern of (2) could not be assigned to any database entry. The structure was solved from the powder diffraction pattern leading to the first description of compound $\left[\mathrm{Bi}(\mathrm{pydc})\left(\mathrm{NO}_{3}\right)_{2}\left(\mathrm{H}_{2} \mathrm{O}\right)_{2}\right] \cdot \mathrm{H}_{2} \mathrm{O}$.

\section{Structure of $\left(\mathrm{H}_{2} \mathrm{Im}\right)\left[\mathrm{Bi}(1,4-\mathrm{bdc})_{2}\right](1)$}

The mechanochemically synthesised three-dimensional metal organic framework $\left(\mathrm{H}_{2} \operatorname{Im}\right)\left[\mathrm{Bi}(1,4-\mathrm{bdc})_{2}\right](\mathbf{1})$ crystallises in the rhombohedral space group $R-3 c$. The crystal data of this structure are summarised in Table 1 . The asymmetric unit cell consists of two different $\mathrm{Bi}^{3+}$ cations, one benzene-1,4-dicarboxylate anion, and one imidazole cation. The two $\mathrm{Bi}^{3+}$ cations Bi1 and Bi2 are present in the ratio of $1(\mathrm{Bi} 1)$ to $2(\mathrm{Bi} 2)$. Both are holodirected with a stereochemically inactive lone pair. Bi1 is twelve-coordinated and Bi2 is nine-coordinated by six different benzene-1,4-dicarboxylate molecules. The connection between the benzene-1,4-dicarboxylate molecules and the bismuth polyhedra results in a three-dimensional framework (Fig. 2). ${ }^{1,3,12}$

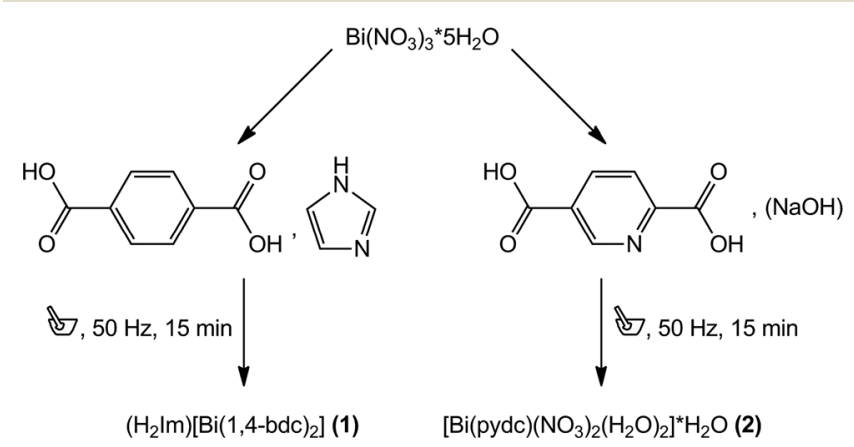

Scheme 1 Reaction scheme of the syntheses of $\left(\mathrm{H}_{2} \mathrm{Im}\right)\left[\mathrm{Bi}(1,4-\mathrm{bdc})_{2}\right]$ (1) (left) and $\left[\mathrm{Bi}\left(\right.\right.$ pydc) $\left.\left(\mathrm{NO}_{3}\right)_{2}\left(\mathrm{H}_{2} \mathrm{O}\right)_{2}\right] \cdot \mathrm{H}_{2} \mathrm{O}$ (2) (right).
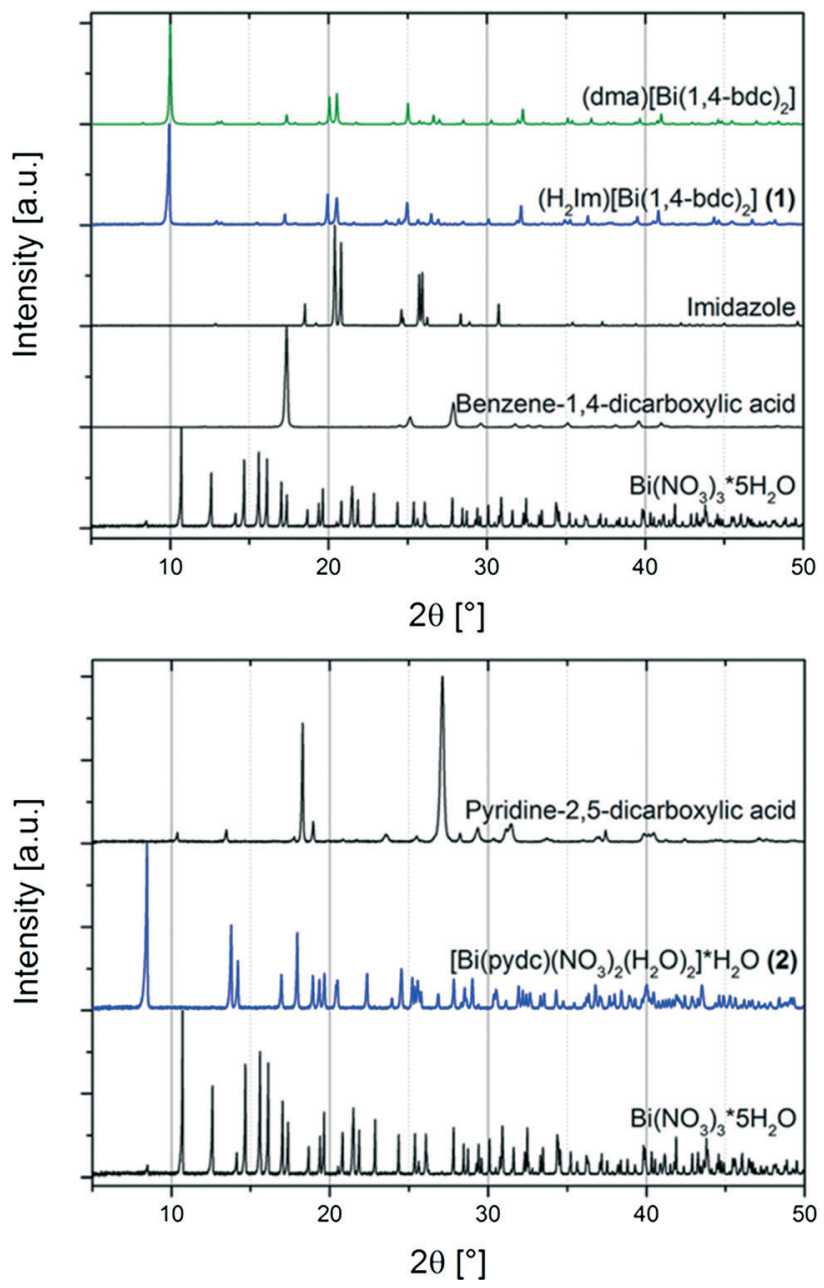

Fig. 1 Top: powder XRD patterns of the metal organic compound $\left(\mathrm{H}_{2} \mathrm{~lm}\right)\left[\mathrm{Bi}(1,4-\mathrm{bdc})_{2}\right]$ (1) (blue) and starting materials (black) bismuth(III) nitrate pentahydrate $\left(\mathrm{Bi}\left(\mathrm{NO}_{3}\right)_{3} \cdot 5 \mathrm{H}_{2} \mathrm{O}\right)$, benzene-1,4-dicarboxylic acid, and imidazole; and the powder XRD pattern for comparison of (dma) $\left[\mathrm{Bi}(1,4-\mathrm{bdc})_{2}\right]$ (green) simulated based on its crystal structure (CCDC 776715, CSD-XAFBOX). ${ }^{12}$ Bottom: powder XRD patterns of the synthesised metal organic structure $\left[\mathrm{Bi}\left(\right.\right.$ pydc) $\left.\left(\mathrm{NO}_{3}\right)_{2}\left(\mathrm{H}_{2} \mathrm{O}\right)_{2}\right] \cdot \mathrm{H}_{2} \mathrm{O}(2)$ (blue) and starting materials (black) bismuth(III) nitrate pentahydrate $\left(\mathrm{Bi}\left(\mathrm{NO}_{3}\right)_{3} \cdot 5 \mathrm{H}_{2} \mathrm{O}\right)$ and pyridine-2,5-dicarboxylic acid.

EXAFS measurements at the $\mathrm{Bi} \mathrm{L}_{3}$-edge were performed for compound (1). These measurements provide information about the coordination environment of the $\mathrm{Bi}^{3+}$ cations. EXAFS data of structure (1) shown in real space are given in Fig. 3, left and the corresponding fit parameters are summarized in Table 2. The fitted comparison data were calculated based on the crystal structure. For the evaluation, single-scattering paths of the first coordination shell of the Bi centres were used. A good agreement of the experimental data with the fit results could be proven. The root mean square error (RMSE) of the atom distances of structure $\left(\mathrm{H}_{2} \operatorname{Im}\right)\left[\mathrm{Bi}(1,4-\mathrm{bdc})_{2}\right]$ (1) is $0.145 \AA$ A. This proves a good agreement of the theoretical atom distances with the experimentally obtained distances. Thus, the crystal structure and especially the coordination spheres of the two $\mathrm{Bi}^{3+}$ cations can be proven by EXAFS measurements. 
Table 1 Crystal data and structure refinement parameters of $\left(\mathrm{H}_{2} \mathrm{Im}\right)\left[\mathrm{Bi}(1,4-\mathrm{bdc})_{2}\right](1)^{12}$ and $\left[\mathrm{Bi}(\mathrm{pydc})\left(\mathrm{NO}_{3}\right)_{2}\left(\mathrm{H}_{2} \mathrm{O}\right)_{2}\right] \cdot \mathrm{H}_{2} \mathrm{O}(2)$

\begin{tabular}{lll}
\hline Structure parameter & $\left(\mathrm{H}_{2} \mathrm{Im}\right)\left[\mathrm{Bi}(1,4-\mathrm{bdc})_{2}\right](1)$ & {$\left[\mathrm{Bi}(\mathrm{pydc})\left(\mathrm{NO}_{3}\right)_{2}\left(\mathrm{H}_{2} \mathrm{O}\right)_{2}\right] \cdot \mathrm{H}_{2} \mathrm{O}(2)$} \\
\hline Empirical formula & $\mathrm{C}_{19} \mathrm{H}_{13} \mathrm{~N}_{2} \mathrm{O}_{8} \mathrm{Bi}$ & $\mathrm{C}_{7} \mathrm{H}_{9} \mathrm{~N}_{3} \mathrm{O}_{13} \mathrm{Bi}$ \\
Formula weight $\left(\mathrm{g} \mathrm{mol}^{-1}\right)$ & 606.30 & 552.14 \\
Crystal system & $\mathrm{Rhombohedral}$ & Triclinic \\
Space group & $R-3 c$ & $P 1$ \\
$a(\AA)$ & $17.6932(7)$ & $5.10416(9)$ \\
$b(\AA)$ & $17.6932(7)$ & $6.8558(3)$ \\
$c(\AA)$ & $29.7350(9)$ & $10.8069(2)$ \\
$\alpha(\circ)$ & 90 & $104.328(1)$ \\
$\beta(\circ)$ & 90 & $90.119(1)$ \\
$\gamma\left({ }^{\circ}\right)$ & 120 & $104.302(1)$ \\
$V\left(\AA^{3}\right)$ & $8061.42(68)$ & $354.23(1)$ \\
$Z$ & 18 & 1 \\
$D_{\text {calc }}\left(\mathrm{g} \mathrm{cm} \mathrm{cm}^{-3}\right)$ & 2.163 & \\
$R_{\text {wp }}$ & & 2.557 \\
$R_{\text {Bragg }}$ & & 10.4 \\
GOF & & 5.156
\end{tabular}

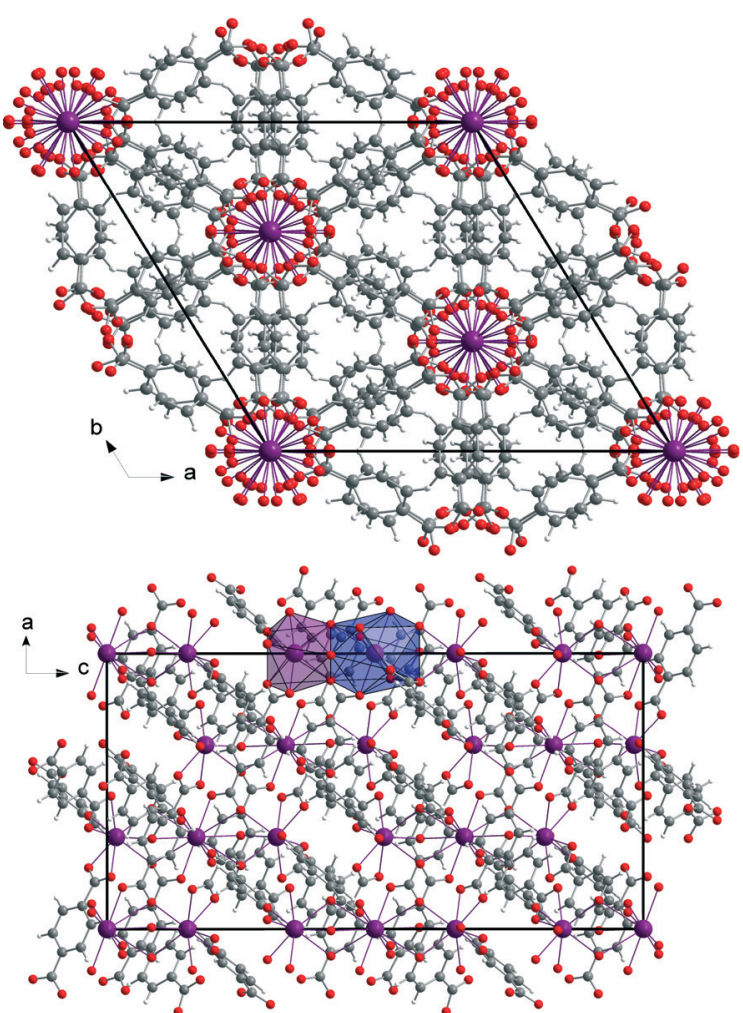

Fig. 2 View of the three-dimensional structure $\left(\mathrm{H}_{2} \mathrm{Im}\right)\left[\mathrm{Bi}(1,4-\mathrm{bdc})_{2}\right](1)$ seen along the $c$-axis (top) and the $b$-axis (bottom). The coordination polyhedra of both $\mathrm{Bi}^{3+}$ cations are given in blue (Bi1, twelvecoordinated) and violet ( $\mathrm{Bi} 2$, nine-coordinated) in the view of the a-c plane (bottom).

\section{Structure of $\left[\mathrm{Bi}(\mathrm{pydc})\left(\mathrm{NO}_{3}\right)_{2}\left(\mathrm{H}_{2} \mathrm{O}\right)_{2}\right] \cdot \mathrm{H}_{2} \mathrm{O}$ (2)}

The crystal structure of $\left[\mathrm{Bi}(\mathrm{pydc})\left(\mathrm{NO}_{3}\right)_{2}\left(\mathrm{H}_{2} \mathrm{O}\right)_{2}\right] \cdot \mathrm{H}_{2} \mathrm{O}(2)$ was calculated based on its powder diffraction data. Fig. 4 shows the result of the Rietveld refinement illustrating the good agreement of the simulated powder pattern with the measured one. The refinement converged at $R_{\mathrm{wp}}=10.4 \%$. The crystal data are given in Table 1. $\left[\mathrm{Bi}(\right.$ pydc $\left.)\left(\mathrm{NO}_{3}\right)_{2}\left(\mathrm{H}_{2} \mathrm{O}\right)_{2}\right] \cdot \mathrm{H}_{2} \mathrm{O}$ (2) crystallises in the triclinic space group $P 1, Z=1$, with unit cell parameters
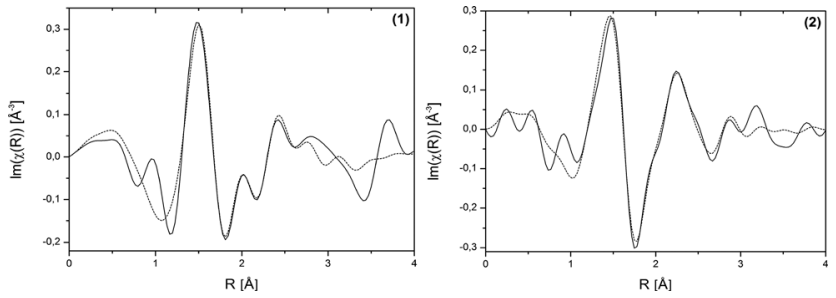

Fig. 3 Bi $\mathrm{L}_{3}$-edge EXAFS data shown in real space of $\left(\mathrm{H}_{2} \mathrm{Im}\right)\left[\mathrm{Bi}(1,4-\mathrm{bdc})_{2}\right]$ (1) and $\left[\mathrm{Bi}\left(\right.\right.$ pydc) $\left.\left(\mathrm{NO}_{3}\right)_{2}\left(\mathrm{H}_{2} \mathrm{O}\right)_{2}\right] \cdot \mathrm{H}_{2} \mathrm{O}$ (2). Experimental data - solid line, fit results - dotted line.

Table 2 EXAFS fit parameters of $\left(\mathrm{H}_{2} \mathrm{Im}\right)\left[\mathrm{Bi}(1,4-\mathrm{bdc})_{2}\right]$ (1) and $\left[\mathrm{Bi}\left(\right.\right.$ pydc) $\left.\left(\mathrm{NO}_{3}\right)_{2}\left(\mathrm{H}_{2} \mathrm{O}\right)_{2}\right] \cdot \mathrm{H}_{2} \mathrm{O}$ (2). Root mean square error (RMSE) of $\left(\mathrm{H}_{2} \mathrm{Im}\right)\left[\mathrm{Bi}(1,4-\mathrm{bdc})_{2}\right](1)$ is $0.145 \AA$ and of $\left[\mathrm{Bi}(\right.$ pydc $\left.)\left(\mathrm{NO}_{3}\right)_{2}\left(\mathrm{H}_{2} \mathrm{O}\right)_{2}\right] \cdot \mathrm{H}_{2} \mathrm{O}(2)$ is $0.249 \AA$

\begin{tabular}{lllll}
\hline Sample & Scattering path & $R_{\text {model }}[\AA]$ & $R_{\text {fit }}[\AA]$ & $R_{\text {diff }}^{2}\left[\AA^{2}\right]$ \\
\hline (1) & Bi1-O1 & 2.49 & 2.35 & 0.0169 \\
& Bi1-O2 & 3.04 & 3.10 & 0.0036 \\
& Bi1-C1 & 3.13 & 3.37 & 0.0576 \\
Bi2-O3 & 2.31 & 2.21 & 0.0081 \\
Bi2-O4 & 2.61 & 2.54 & 0.0036 \\
& Bi2-O2 & 2.67 & 2.75 & 0.0049 \\
Bi2-C8 & 2.81 & 3.04 & 0.0529 \\
(2) & Bi1-O6 & 2.34 & 2.26 & 0.0064 \\
Bi1-O10 & 2.53 & 2.26 & 0.0729 \\
Bi1-N6 & 2.53 & 2.13 & 0.1681 \\
Bi1-O13 & 2.57 & 2.36 & 0.0441 \\
Bi1-O5 & 2.59 & 2.49 & 0.0100 \\
Bi1-O2 & 2.65 & 2.57 & 0.0064 \\
Bi1-O2 & 2.71 & 2.87 & 0.0256 \\
Bi1-O11 & 2.79 & 3.10 & 0.0961 \\
Bi1-O8 & 2.80 & 2.77 & 0.0009 \\
Bi1-N2 & 2.96 & 3.02 & 0.0036 \\
Bi1-O1 & 3.11 & 3.32 & 0.0441 \\
Bi1-N1 & 3.17 & 3.49 & 0.0961 \\
Bi1-N1 & 3.20 & 3.63 & 0.1849 \\
Bi1-C3 & 3.24 & 3.17 & 0.0064 \\
Bi1-C5 & 3.34 & 3.65 & 0.0961 \\
Bi1-C1 & 3.47 & 3.83 & 0.1296
\end{tabular}

of $a=5.10416(9) \AA, \quad b=6.8558(3) \AA, c=10.8069(2) \AA$, $\alpha=104.328(1)^{\circ}, \beta=90.119(1)^{\circ}, \gamma=104.302(1)^{\circ}$, and $V=354.23(1) \AA^{3}$. 


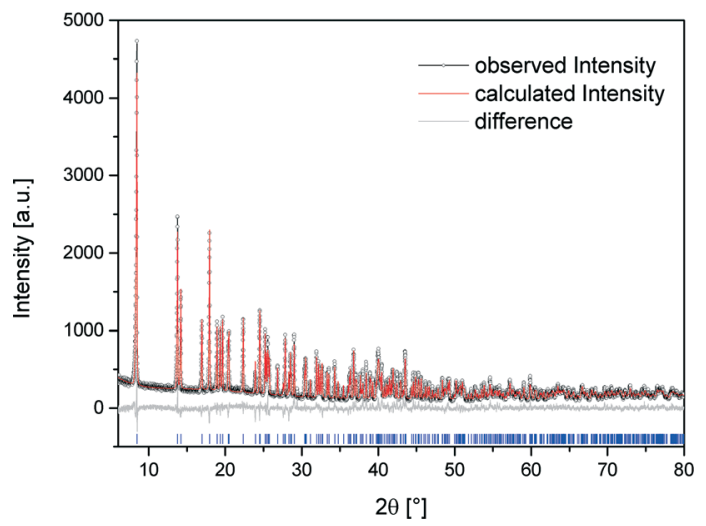

Fig. 4 Scattered X-ray intensity of structure (2) under ambient conditions as a function of diffraction angle $2 \theta$. The observed pattern (circles), the best Rietveld fit profile (red line), the reflection positions (blue tick marks), and the difference curve (grey line) between observed and calculated profiles are shown. The wavelength is $\lambda=1.54056 \AA$ $\left(\mathrm{Cu}-\mathrm{K}_{1}\right)$. The $R$-values are $R_{\mathrm{p}}=8.0 \%, R_{\mathrm{wp}}=10.4 \%$; for $R_{\mathrm{p}}$ and $R_{\mathrm{wp}}$, refer to the Rietveld criteria of fit for profile, weighted profile, and structure factor, as defined by Langford and Louer. ${ }^{28}$

The asymmetric unit cell contains one $\mathrm{Bi}^{3+}$ cation, one pyridine-2,5-dicarboxylate anion, two nitrate anions and three water molecules. The $\mathrm{Bi}^{3+}$ cation is nine-coordinated and holodirected with a stereochemically inactive lone pair of electrons. The $\mathrm{Bi}^{3+}$ cation coordinates bidentate to the nitrogen atom and one carboxylate oxygen atom of the pyridine2,5-dicarboxylate molecule. The coordination environment is completed by two water molecules, two nitrate units coordinating bidentate, and a third nitrate anion coordinating monodentate. In addition, one uncoordinated water molecule is near the second carboxylate unit of pyridine-2,5-dicarboxylate. The $\mathrm{Bi}-\mathrm{N}$ bond length is $2.533 \AA$ and the $\mathrm{Bi}-\mathrm{O}$ bond lengths are in the range of $2.337-2.798 \AA$. The monodentate coordinated nitrate anion connects this complex to the adjacent $\mathrm{Bi}^{3+}$ cations. Consequently, a one-dimensional chain of ninecoordinated $\mathrm{Bi}^{3+}$ cations is formed (Fig. 5). The chains are arranged parallel to each other running along the $a$-axis.

The coordination sphere around the $\mathrm{Bi}^{3+}$ cation and thereby the crystal structure of compound (2) could be supported by EXAFS measurements conducted at the $\mathrm{Bi}_{3}$-edge. EXAFS data shown in real space and the fit parameters are given in Fig. 4, right and Table 2. The fitted comparison data, based on the crystal structure from the powder diffraction pattern, showed a good agreement with the experimental data. The first scattering path was used for evaluation. The RMSE of the atom distances of structure $\left[\mathrm{Bi}(\mathrm{pydc})\left(\mathrm{NO}_{3}\right)_{2}\left(\mathrm{H}_{2} \mathrm{O}\right)_{2}\right] \cdot \mathrm{H}_{2} \mathrm{O}(2)$ is $0.249 \AA$. This proves a good agreement of the calculated atom distances with the experimental distances.

Like other bismuth carboxylates described in the literature, compounds (1) and (2) show the ability of bismuth to adopt a high coordination environment; typical coordination numbers are eight or nine. ${ }^{29-32}$ The $\mathrm{Bi}-\mathrm{O}$ distances in these structures range between 2.21 and $3.13 \AA$. The Raman spectra of both structures $\left(\mathrm{H}_{2} \mathrm{Im}\right)\left[\mathrm{Bi}(1,4-\mathrm{bdc})_{2}\right](\mathbf{1})$ and $\left[\mathrm{Bi}(\mathrm{pydc})\left(\mathrm{NO}_{3}\right)_{2}\left(\mathrm{H}_{2} \mathrm{O}\right)_{2}\right] \cdot \mathrm{H}_{2} \mathrm{O}$ (2) as well as of the starting materials are shown in Fig. 6.

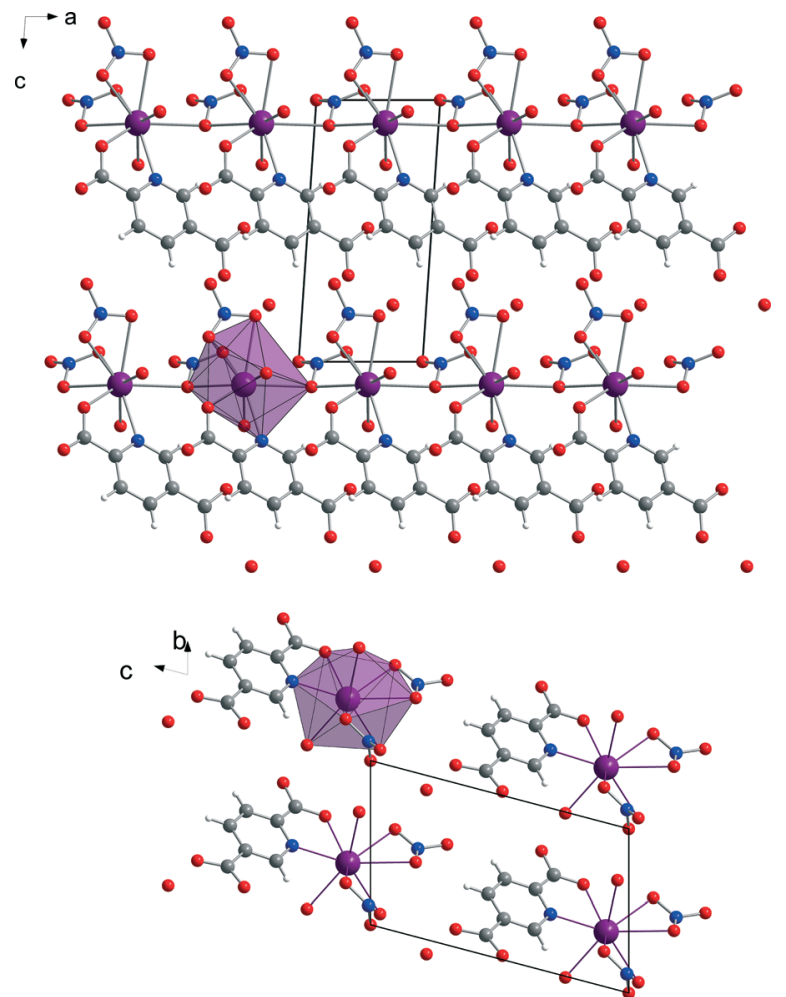

Fig. 5 View of the chain structure $\left[\mathrm{Bi}\left(\right.\right.$ pydc) $\left.\left(\mathrm{NO}_{3}\right)_{2}\left(\mathrm{H}_{2} \mathrm{O}\right)_{2}\right] \cdot \mathrm{H}_{2} \mathrm{O}$ (2) along the $b$-axis (top). Representation of the packing of the molecules in a projection along the a-axis (bottom). For each projection, the polyhedron around one $\mathrm{Bi}^{3+}$ cation is shown in violet. The hydrogen atoms of the water molecules are omitted for clarity.

Compounds (1) and (2) show characteristic Raman bands and comparison to the Raman spectra of the respective starting materials bismuth(III) nitrate pentahydrate, pyridine2,5-dicarboxylic acid, benzene-1,4-dicarboxylic acid and imidazole proves the completeness of the reaction. Both structures (1) and (2) show a few similar Raman bands to the ligands

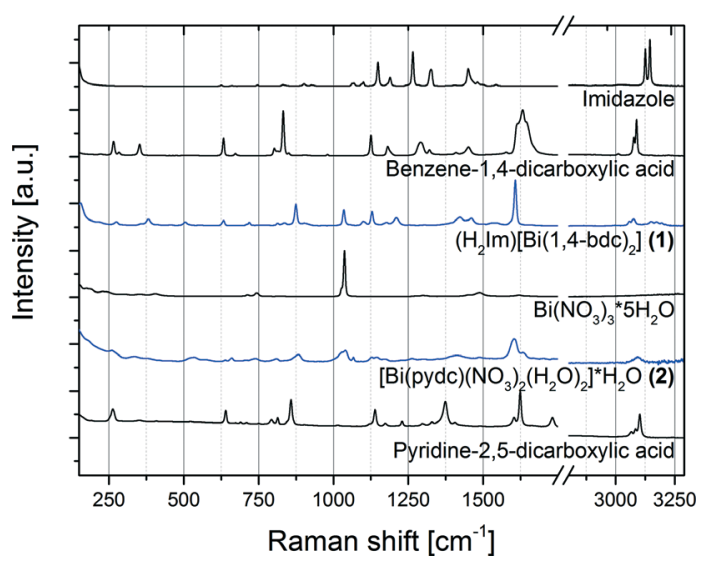

Fig. 6 Raman spectra of the products $\left(\mathrm{H}_{2} \mathrm{Im}\right)\left[\mathrm{Bi}(1,4-\mathrm{bdc})_{2}\right]$ (1) and [Bi(pydc) $\left.\left(\mathrm{NO}_{3}\right)_{2}\left(\mathrm{H}_{2} \mathrm{O}\right)_{2}\right] \cdot \mathrm{H}_{2} \mathrm{O}$ (2) (blue) in comparison with the Raman spectra of the starting materials pyridine-2,5-dicarboxylic acid, bismuth(III) nitrate pentahydrate $\left(\mathrm{Bi}\left(\mathrm{NO}_{3}\right)_{3} \cdot 5 \mathrm{H}_{2} \mathrm{O}\right)$, benzene-1,4-dicarboxylic acid and imidazole (black). 
benzene-1,4-dicarboxylic acid and pyridine-2,5-dicarboxylic acid but they are clearly shifted in the products due to deprotonation and new coordination spheres of the ligands in the final products. For the synthesis of compound (1) the protonation of the added imidazole molecule can be verified based on the Raman spectra. Two intensive bands at $1220 \mathrm{~cm}^{-1}$ and $1445 \mathrm{~cm}^{-1}$ characterize the spectrum of the imidazolium ion $\left(\mathrm{H}_{2} \mathrm{Im}\right){ }^{33}$ These bands are clearly detectable in the Raman spectrum of compound (1).

\section{Experimental}

\section{Materials}

Bismuth(III) nitrate pentahydrate $\mathrm{Bi}\left(\mathrm{NO}_{3}\right)_{3} \cdot 5 \mathrm{H}_{2} \mathrm{O}(98 \%$, Alfa Aesar, Karlsruhe, Germany), benzene-1,4-dicarboxylic acid (terephthalic acid) $\mathrm{C}_{6} \mathrm{H}_{4}(\mathrm{COOH})_{2}(98+\%$, Alfa Aesar, Karlsruhe, Germany), imidazole $\mathrm{C}_{3} \mathrm{H}_{4} \mathrm{~N}_{2}(99 \%$, Alfa Aesar, Karlsruhe, Germany) and pyridine-2,5-dicarboxylic acid $\mathrm{C}_{5} \mathrm{NH}_{3}(\mathrm{COOH})_{2}$ (for synthesis, Merck, Hohenbrunn, Germany) were used without further purification. A $1 \mathrm{M}$ sodium hydroxide solution was prepared using solid sodium hydroxide (for analysis, Merck, Darmstadt, Germany) and MilliQ water (18.2 M $\Omega$, ultrapure water system seralpur Pro 90 CN, Seral, Ransbach-Baumbach, Germany).

\section{Sample preparation}

$\left(\mathbf{H}_{2} \mathrm{Im}\right)\left[\mathrm{Bi}(\mathbf{1}, \mathbf{4}-\mathrm{bdc})_{2}\right]$ (1). For a typical synthesis of (1) $\mathrm{Bi}\left(\mathrm{NO}_{3}\right)_{3} \cdot 5 \mathrm{H}_{2} \mathrm{O}$ (590.0 mg, 1 e.q.), benzene-1,4-dicarboxylic acid (404.1 mg, 2 e.q.), and imidazole (331.2 mg, 4 e.q.) were ground together using a conventional ball mill (Pulverisette 23, FRITSCH GmbH, Idar-Oberstein, Germany) for 15 minutes with a frequency of $50 \mathrm{~Hz}$. A $10 \mathrm{~mL}$ steel grinding bowl and two steel balls of $10 \mathrm{~mm}$ diameter were used. The product was obtained as white slurry and dried in air.

$\left[\mathrm{Bi}\left(\right.\right.$ pydc) $\left.\left(\mathrm{NO}_{3}\right)_{2}\left(\mathrm{H}_{2} \mathrm{O}\right)_{2}\right] \cdot \mathrm{H}_{2} \mathrm{O}$ (2). For a typical synthesis of (2), $\mathrm{Bi}\left(\mathrm{NO}_{3}\right)_{3} \cdot 5 \mathrm{H}_{2} \mathrm{O}$ (723.9 mg, 1 e.q.) and pyridine2,5-dicarboxylic acid (249.1 mg, 1 e.q.) were ground together with $200 \mu \mathrm{L}$ of $\mathrm{NaOH}$ solution $(1 \mathrm{M})$ using a conventional ball mill (Pulverisette 23, FRITSCH GmbH, Idar-Oberstein, Germany) equipped with a $10 \mathrm{~mL}$ steel grinding bowl and two steel balls $(10 \mathrm{~mm})$. The product was obtained as whitegrey slurry and dried in air.

\section{Methods}

Powder diffraction measurements. Powder diffraction measurements were performed using a D8 Discover diffractometer (Bruker AXS, Karlsruhe, Germany) equipped with a Lynxeye detector and operated in transmission geometry $\left(\mathrm{Cu}-\mathrm{K} \alpha_{1}\right.$ radiation, $\left.\lambda=0.154056 \mathrm{~nm}\right)$. Samples were measured over a $2 \theta$ range of $5-80^{\circ}$ with a step size of $0.009^{\circ}$ and 0.5 to $2.5 \mathrm{~s}$ per step.

Structure determination. For the high resolution X-ray powder diffraction experiments, the sample was sealed in a glass capillary of $0.5 \mathrm{~mm}$ diameter (WJM-Glas, Müller GmbH, Berlin, Germany). Powder diffraction data were collected at room temperature. Indexing of the powder pattern of (2) using the indexing module of TOPAS ${ }^{34}$ led to a primitive triclinic unit cell with lattice parameters given in Table 1 . The number of formula units per unit cell was determined to be $Z=1$ from packing considerations, indicating $P 1$ as the most probable space group, which could later be confirmed by Rietveld refinement. The unit cell and space group were confirmed using CHEKCELL. ${ }^{35}$ The structure determination of $\left[\mathrm{Bi}(\right.$ pydc $\left.)\left(\mathrm{NO}_{3}\right)_{2}\left(\mathrm{H}_{2} \mathrm{O}\right)_{2}\right] \cdot \mathrm{H}_{2} \mathrm{O}$ (2) was carried out based on the powder XRD pattern. A structural starting model of Rietveld refinement was subsequently found using the Monte Carlo simulated annealing programme FOX. ${ }^{36}$ This programme uses global-optimization algorithms to solve the structure by performing trials in direct space. This search algorithm uses random sampling coupled with simulated temperature annealing to locate the global minimum of the figure-of-merit factor. Parts of the molecule were refined as a rigid group to reduce the total number of degrees of freedom. Both nitrate molecules were set rigid, while pyridine-2,5-dicarboxylate was set rigid with the exception of the carboxyl oxygen and hydrogen atoms. In addition, a bond between the $\mathrm{Bi}$ atom and the nitrogen and one carboxyl oxygen atom of pyridine2,5-dicarboxylate was assigned. The crystal structure of $\left[\mathrm{Bi}(\mathrm{pydc})\left(\mathrm{NO}_{3}\right)_{2}\left(\mathrm{H}_{2} \mathrm{O}\right)_{2}\right] \cdot \mathrm{H}_{2} \mathrm{O}(2)$ was solved by the simulated annealing procedure. The calculation process was carried out using a standard personal computer within 20 hours, finding the deepest minimum of the cost function several times during the procedure. The subsequent Rietveld refinement was performed using the TOPAS software. ${ }^{34}$ The structural solution obtained from MC/SA was subsequently subjected to a Rietveld refinement. The refinement converged at $R_{\mathrm{wp}}=10.4 \%$. Selected bond lengths and angles of compound (2) are given in the $\mathrm{ESI}^{\dagger}$ (S-Table 1 and S-Table 2).

Raman spectroscopy. The Raman spectra were collected using a Raman RXN1 ${ }^{\mathrm{TM}}$ analyzer (Kaiser Optical Systems, Inc., Ecully, France) with NIR excitation radiation at $785 \mathrm{~nm}$. The spectrometer is equipped with a CCD camera $(1024 \times$ 256 pixels) and a non-contact probe head (working distance $15 \mathrm{~mm}$, spot size $1 \mathrm{~mm} \emptyset$ ). The Raman spectra were recorded with an acquisition time of $5 \times 5 \mathrm{~s}$ and an irradiance of $6.6 \mathrm{~W}$ $\mathrm{cm}^{-2}$ on the sample.

EXAFS measurements. For the EXAFS measurements, both products were mixed with activated carbon and fixed in plastic sample holders. EXAFS measurements were performed at the electron storage ring BESSY II (Helmholtz-Zentrum Berlin für Materialien und Energie $\mathrm{GmbH}$, Berlin, Germany) at the BAMline. ${ }^{37,38}$ The X-ray beam was monochromatised using a double-crystal monochromator (DCM). The size of the beam spot was $3 \times 1 \mathrm{~mm}^{2}$. The energy resolution of the setup was about 0.00015 , leading to $\Delta E=2.0 \mathrm{eV}$ while measuring at the $\mathrm{Bi}_{3}$ edge (13.419 keV). The excitation energy was varied from 13.250 to $14.271 \mathrm{keV}$ in steps of $10 \mathrm{eV}$ pre-edge, $1 \mathrm{eV}$ at the edge and $\Delta k=0.04$ in the $k$-space of the EXAFS region. Measurements were performed in transmission geometry. The first ionisation chamber was filled with argon (1 bar) and the second was filled with xenon (1 bar). The EXAFS data were evaluated using the programmes Athena, Artemis, and 
Hephaestus. $^{39}$ The model spectra of the fits were calculated using the FEFF9 code. ${ }^{40}$

Elemental analysis. To exclude the presence of X-ray amorphous impurities, elemental analyses were conducted. The results are in good agreement with the expected values. Compound (1): $\mathrm{BiC}_{19} \mathrm{H}_{13} \mathrm{O}_{8} \mathrm{~N}_{2}$ (606.30 $\mathrm{g} \mathrm{mol}^{-1}$ ): calculated: $\mathrm{C} 37.64 \%$, $\mathrm{H} 2.16 \%$, N 4.62\%; found: C 32.05\%, H 3.10\%, N 4.85\%. Compound (2): $\mathrm{BiC}_{7} \mathrm{H}_{9} \mathrm{~N}_{3} \mathrm{O}_{13}\left(552.13 \mathrm{~g} \mathrm{~mol}^{-1}\right)$ : calculated: $\mathrm{C} 15.23 \%$, H 1.64\%, N 7.61\%; found: C 14.38\%, H 1.73\%, N 7.78\%.

\section{Conclusions}

Two metal organic compounds containing bismuth and benzene-1,4-dicarboxylate or pyridine-2,5-dicarboxylate as ligand were synthesised mechanochemically. The crystal structure of compound (1) was identified based on its powder diffraction data. The crystal structure of the bismuth and pyridine2,5-dicarboxylate containing compound (2) could be calculated from its powder diffraction pattern. The mechanochemical synthesis pathway revealed a fast, efficient, and solvent free access to both compounds. For both structures, Raman spectra and EXAFS measurements revealed a good agreement of the calculated crystalline structures and the bismuth coordination spheres.

\section{Notes and references}

1 S. Bauer and N. Stock, Chem. Unserer Zeit, 2008, 42, 12-19.

2 G. Ferey, Chem. Soc. Rev., 2008, 37, 191-214.

3 J. L. C. Rowsell and O. M. Yaghi, Microporous Mesoporous Mater., 2004, 73, 3-14.

4 C. Janiak and J. K. Vieth, New J. Chem., 2010, 34, 2366-2388.

5 M. Eddaoudi, J. Kim, N. Rosi, D. Vodak, J. Wachter, M. O'Keeffe and O. M. Yaghi, Science, 2002, 295, 469-472.

6 L. F. Ma, Y. Y. Wang, L. Y. Wang, D. H. Lu, S. R. Batten and J. G. Wang, Cryst. Growth Des., 2009, 9, 2036-2038.

7 B. L. Chen, S. C. Xiang and G. D. Qian, Acc. Chem. Res., 2010, 43, 1115-1124.

8 C. Janiak, Dalton Trans., 2003, 2781-2804.

9 G. Scholz, F. Emmerling, M. Dreger and E. Kemnitz, Z. Anorg. Allg. Chem., 2013, 639, 689-693.

10 S. R. Miller, E. Alvarez, L. Fradcourt, T. Devic, S. Wuttke, P. S. Wheatley, N. Steunou, C. Bonhomme, C. Gervais, D. Laurencin, R. E. Morris, A. Vimont, M. Daturi, P. Horcajada and C. Serre, Chem. Commun., 2013, 49, 7773-7775.

11 R. Babarao and J. W. Jiang, Langmuir, 2008, 24, 6270-6278.

12 A. Thirumurugan and A. K. Cheetham, Eur. J. Inorg. Chem., 2010, 3823-3828.

13 W. H. Bi, N. Leblanc, N. Mercier, P. Auban-Senzier and C. Pasquier, Chem. Mater., 2009, 21, 4099-4101.

14 V. Andre, A. Hardeman, I. Halasz, R. S. Stein, G. J. Jackson, D. G. Reid, M. J. Duer, C. Curfs, M. T. Duarte and T. Friscic, Angew. Chem., Int. Ed., 2011, 50, 7858-7861.
15 P. C. Andrews, G. B. Deacon, C. M. Forsyth, P. C. Junk, I. Kumar and M. Maguire, Angew. Chem., Int. Ed., 2006, 45, 5638-5642.

16 A. C. Wibowo, M. D. Smith and H. C. zur Loye, Cryst. Growth Des., 2011, 11, 4449-4457.

17 A. C. Wibowo, M. D. Smith, J. Yeon, P. S. Halasyamani and H. C. zur Loye, J. Solid State Chem., 2012, 195, 94-100.

18 A. Thirumurugan, W. Li and A. K. Cheetham, Dalton Trans., 2012, 41, 4126-4134.

19 S. Busch, I. Stein and U. Ruschewitz, Z. Anorg. Allg. Chem., 2012, 638, 2098-2101.

20 M. Feyand, M. Koppen, G. Friedrichs and N. Stock, Chem. Eur. J., 2013, 19, 12537-12546.

21 S. R. Sushrutha and S. Natarajan, Cryst. Growth Des., 2013, 13, 1743-1751.

22 M. Klimakow, P. Klobes, A. F. Thunemann, K. Rademann and F. Emmerling, Chem. Mater., 2010, 22, 5216-5221.

23 M. Klimakow, P. Klobes, K. Rademann and F. Emmerling, Microporous Mesoporous Mater., 2012, 154, 113-118.

24 A. Delori, T. Friscic and W. Jones, CrystEngComm, 2012, 14, 2350-2362.

25 T. Friscic, I. Halasz, V. Strukil, M. Eckert-Maksic and R. E. Dinnebier, Croat. Chem. Acta, 2012, 85, 367-378.

26 S. Heiden, L. Tröbs, K. J. Wenzel and F. Emmerling, CrystEngComm, 2012, 14, 5128-5129.

27 V. Strukil, L. Fabian, D. G. Reid, M. J. Duer, G. J. Jackson, M. Eckert-Maksic and T. Friscic, Chem. Commun., 2010, 46, 9191-9193.

28 J. I. Langford and D. Louer, Rep. Prog. Phys., 1996, 59, 131-234.

29 P. C. Andrews, G. B. Deacon, W. R. Jackson, M. Maguire, N. M. Scott, B. W. Skelton and A. H. White, J. Chem. Soc., Dalton Trans., 2002, 4634-4638.

30 P. C. Andrews, G. B. Deacon, P. C. Junk, I. Kumar and M. Silberstein, Dalton Trans., 2006, 4852-4858.

31 T. Hatanpaa, M. Vehkamaki, M. Ritala and M. Leskela, Dalton Trans., 2010, 39, 3219-3226.

32 P. C. Andrews, V. L. Blair, R. L. Ferrero, P. C. Junk and I. Kumar, Chem. Commun., 2013, 49, 2870-2872.

33 L. M. Markham, L. C. Mayne, B. S. Hudson and M. Z. Zgierski, J. Phys. Chem., 1993, 97, 10319-10325.

34 T. V. 2.0, Bruker AXS, Karlsruhe (Germany), 2000.

35 J. Laugier and B. Bochu, Chekcell, 2001.

36 V. Favre-Nicolin and R. Cerny, J. Appl. Crystallogr., 2002, 35, 734-743.

37 H. Riesemeier, K. Ecker, W. Gorner, B. R. Muller, M. Radtke and M. Krumrey, X-Ray Spectrom., 2005, 34, 160-163.

38 W. Gorner, M. P. Hentschel, B. R. Muller, H. Riesemeier, M. Krumrey, G. Ulm, W. Diete, U. Klein and R. Frahm, Nucl. Instrum. Methods Phys. Res., Sect. A, 2001, 467, 703-706.

39 B. Ravel and M. Newville, J. Synchrotron Radiat., 2005, 12, 537-541.

40 J. J. Rehr, J. J. Kas, F. D. Vila, M. P. Prange and K. Jorissen, Phys. Chem. Chem. Phys., 2010, 12, 5503-5513. 